\title{
PENGARUH RASIO KEUANGAN, FIRM SIZE DAN REPUTASI AUDITORTERHADAP PERINGKAT OBLIGASI PADA PERUSAHAAN YANG TERDAFTAR DI BURSA EFEK INDONESIA PERIODE 2013-2016
}

\author{
OLEH \\ Jermi Julianus Agung \\ Buyung Sarita \\ Riski Amalia Madi \\ (Jurusan Manajemen Fakultas Ekonomi dan Bisnis Universitas Halu Oleo Kendari)
}

\begin{abstract}
ABSTRAK
Penelitian ini bertujuan untuk memberikan bukti empiris tentang faktor yang mempengaruhi peringkat obligasi.vareabel yang digunakan dalam penelitian ini terdiri dari rasio profitiabilitas, rasio likuiditas, rasio solvabilitas, firm size dan reputasi auditor .

Sampel dalam penelitian ini diperoleh dengan menggunakan metode purposive sampling yang terdiri atas obligasi yang diterbitkan oleh perusahaan terdaftar di BEI periode 2013-2016 dan diperingkat oleh PT.Pefindo, sehingga diperoleh 40 sampel obligasi.Penelitian ini menggunakan model analisis Regresi Logistik ordinal untuk menguji faktor-faktor yang mempengaruhi peringkat obligasi.

Dari tes kelima variabel independen, variabel dengan pengaruh yang signifikan untuk memprediksi peringkat obligasi adalah profitabilitas dan firm size.Dan variabel yang tidak berpengaruh dalam memprediksi tingkat obligasi adalah rasio likuiditas, rasio solvabilitas dan reputasi auditor.
\end{abstract}

\section{Kata Kunci: Profitabilitas, likuiditas, solvabilitas, firm size, reputasi auditor.}

\section{PENDAHULUAN}

Berinvestasi di obligasi merupakan salah satu sarana investasi yang banyak diminati oleh pemilik modal (investor) karena obligasi memiliki pendapatan yang bersifat tetap, tidak terkecuali oleh investor di indonesia. Menurut Priambodo (2006) obligasi merupakan instrumen utang yang berisi janji dari pihak yang mengeluarkan obligasi untuk membayar pemilik obligasi sejumlah nilai pinjaman beserta bunga. Ketika investor membeli sebuah obligasi, berarti investor meminjamkan sejumlah dana kepada penerbit obligasi tersebut. Imbal hasil dari sebuah obligasi berupa bunga atau yang di kenal dengan istilah kupon.

Darmadji (2011) kelebihan obligasi yaitu obligasi memberikan pendapatan tetap berupa kupon sepanjang umur obligasi. Sedangkan return dari saham berupa deviden tidak memiliki kepastian, karena besaran deviden yang di bayarkan perusahaan di putuskan melalui Rapat Umum Pemegang Saham (RUPS) sehingga besaran deviden yang di bayarkan tidak selalu sama dari waktu ke waktu karena menyesuaikan dengan hasil keputusan RUPS. Selain deviden, keuntungan yang lain yang dapat di peroleh investor dari berinvestasi saham berupa capital gain (selisih harga beli dan harga jual), namun untuk memperoleh keuntungan berupa capital gain investor harus cermat kapan melakukan keputusan beli dan kapan melakukan keputusan jual.Selain keuntungan dari pembayaran bunga investasi diobligasi juga memiliki kesempatan memperoleh keuntungan dari capital gain.Karena seperti saham, obligasi dapat pula di perjualbelikan.

Selain itu berinvestasi di obligasi tidak memerlukan perhatian khusus karena tingkat return yang stabil karena besaran bunga telah ditentukan dari awal sehingga tidak menyita banyak waktu investor, sedang investasi di saham mengharuskan investor untuk selalu melihat pergerakan harga saham karena harga saham sangat fluktuatif terutama bagi investor yang mengutamakan keuntungan dari capital gain, hal ini akan sangat merepotkan bagi investor yang tidak banyak memiliki waktu senggang.

Selain itu berinvestasi di obligasi tergolong lebih aman karena pemegang obligasi mememiliki hak pertama atas aset perusahaan jika terjadi likuidasi terhadap perusahaan, ini artinya hak pemegang obligasi akan di penuhi terlebih dahulu sebelum perusahaan memenuhi kewajiban yang lain, sedangkan pemegang saham akan 
memperoleh hak paling terakhir dari asset perusahaan. Hal tersebut terjadi karena perusahaan telah ada kontrak perjanjian untuk melunasi obligasi yang telah dibeli oleh pemegang obligasi. Dengan kata lain investasi obligasi relatif lebih baik (aman) dibanding investasi saham.

Namun berinvestasi di obligasi bukan tanpa risiko, fenomena gagal bayar obligasi terjadi pada beberapa perusahaan besar yang cukup populer bagi masyarakat Indonesia. PT. Mobile-8 Telecom Tbk, telah gagal bayar 2 kali untuk kupon 15 maret 2009 dan 15 juni 2009 dengan obligasi senilai Rp 675 miliar yang jatuh tempo maret 2012. PT Davomas Abadi Tbk, obligasi senilai 235 juta dolar untuk jatuh tempo 2011 telah gagal bayar sebesar 13,09 juta dolar untuk kupon 5 mei 2009. PT Central Protein prima yang merupakan produsen dan pengolah udang terbesar di Indonesia telah gagal bayar sebesar 17,9 juta dolar (Kompasiana, 2010).

Untuk melakukan investasi pada obligasi, selain diperlukan dana yang cukup, pemilik modal juga memerlukan pengetahuan yang cukup tentang obligasi serta diikuti dengan naluri bisnis yang baik agar bisa menganalisis atau memperkirakan faktor-faktor yang bisa mempengaruhi investasi pada obligasi (Almilia dan Devi, 2007). Karena berinvestasi di obligasi memiliki risiko, maka dari itu penting bagi investor untuk mempunyai informasi yang dijadikan dasar sebelum memutuskan untuk memilih sebuah obligasi.Salah satu sumber informasi yang dapat di jadikan dasar sebelum berinvestasi obligasi, yaitu laporan keuangan keuangan perusahaan penerbit obligasi.Namun dalam melakukan penilaian laporan keuangan perusahaan di perlukan dilakukan analisis laporan keuangan.Menganalisis laporan keuangan tentunya memerlukan pemahaman yang baik mengenai laporan keuangan dan memerlukan banyak waktu dalam melakukan analisis. Tentu saja hal ini kurang di sukai oleh para investor terutama bagi mereka yang tidak memahami mengenai laporan keuangan dan waktu senggang yang banyak untuk melakukan analisis laporan keuangan suatu perusahaan.

Salah satu cara yang simple dalam menilai layak tidak membeli obligasi suatu perusahaan, yaitu melihat peringkat obligasi yang di terbitkan perusahaaan pemeringkat obligasi independen. Peringkat obligasi merupakan salah satu informasi yang digunakan sebagai dasar pertimbangan untuk memutuskan apakah obligasi tersebut layak untuk dijadikan investasi serta mengetahui tingkat risikonya.Peringkat obligasi yang diumumkan ke publik dapat mengurangi asimetri informasi antara perusahaan penerbit obligasi dan investor.Sudana (2009: 127) menyatakan bahwa salah satu bahan pertimbangan investor dalam memilih obligasi yang diterbitkan oleh berbagai perusahaan adalah informasi tentang peringkat obligasi.

Hal ini sesuai dengan signalling theory yang menekankan pentingnya informasi dikeluarkan oleh perusahaan terhadap keputusan investasi pihak di luar perusahaan untuk mengurangi asimetri informasi.Perusahaan memberikan sinyal berupa laporan keuangan yang digunakan lembaga pemeringkat untuk menetapkan peringkat dan investor menggunakan peringkat sebagai sinyal untuk mengetahui kelayakan investasi.

Sejak tahun 1995 obligasi yang diterbitkan melalui penawaran umum wajib diberi peringkat oleh lembaga pemeringkat yang terdaftar di BAPEPAM.Peringkat obligasi merupakan skala risiko dari semua obligasi yang diperdagangkan.Skala ini menunjukkan sebarapa aman suatu obligasi bagi investor yang ditunjukan oleh kemampuan perusahaan dalam membayar bunga dan pokok pinjaman. Peringkat obligasi merupakan salah satu acuan dari investor ketika akan memutuskan membeli suatu obligasi. Ketika peringkat obligasi suatu entitas berada pada kategori tinggi (investment grade) berarti lembaga pemeringkat menganggap kinerja perusahaan baik. Informasi tersebut akan direspon oleh investor dengan cara mengalokasikan dananya keperusahaan karena investor menganggap perusahan tersebut dapat meningkatkan kesejahteraannya, akibatnya abnormal return akan meningkat. Sebaliknya, jika terjadi peringkat obligasi rendah (non investment grade) menunjukkan kinerja perusahaan mengalami penurunan.Akibatnya investor kurang tertarik menginvestasikan dananya ke perusahaan tersebut.

Pada penelitian terdahulu, Horrigan (1996) dan Grace (2010) menyatakan bahwa rasio likuiditas tidak berpengaruh signifikan terhadap peringkat obligasi.Hasil penelitian ini tidak sesuai dengan hasil penelitian yang dilakukan Burton (1998) yang menunjukkan bahwa variabel likuiditas yang diukur dengan rasio lancar mempunyai pengaruh terhadap prediksi peringkat obligasi.

Menurut Harahap (2006:304) profitabilitas menggambarkan kemampuan perusahaan mendapatkan laba melalui semua kemampuan dan sumber yang ada seperti kegiatan penjualan, kas, modal, jumlah karyawan, jumlah cabang dan sebagainya. 
Penelitian oleh Manurung (2009), Magreta (2009) dan Bram (2010) menunjukkan profitabilitas berpengaruh signifikan positif terhadap peringkat obligasi.Hal ini bertentangan dengan penelitian Luciana (2007) dan Grace (2010).

Menurut Harahap (2013) solvabilitas adalah rasio yang menggambarkan hubungan antara utang perusahaan terhadap modal, rasio ini dapat melihat seberapa jauh perusahaan dibiayai oleh utang atau pihak luar dengan kemampuan perusahaan yang digambarkan oleh modal.Magreta (2009), Manurung (2009), Bram (2010) menemukan solvabilitas tidak berpengaruh signifikan terhadap peringkat obligasi, namun berbeda dengan hasil penelitian yang dilakukann Satoto (2011) menemukan bahwa solvabilitasberpengaruh positif dan signifikan.

Ukuran perusahaan (frim size) secara umum dapat diartikan sebagai suatu skala yang mengklasifikasikan besar atau kecilnya suatu perusahaan dengan berbagai cara antara lain dinyatakan dalam total aset, total penjualan, nilai pasar saham, dan lain-lain.Penelitian yang dilakukan Surya (2015) yang mengkaji pengaruh frim size terhadap peringkat obligasi menemukan pengaruh yang positif.Sejalan itu dengan penelitian yang di lakukan oleh Sejati (2010) yang juga menemukan pengaruh positif antara frim size dan peringkat obligasi. Namun bertentangan dengan penelitian Almilia dan Devi (2007) yang membuktikan bahwa peringkat obligasi tidak memiliki hubungan yang signifikan positif dengan ukuran perusahaan (frim size)

Raputasi auditor digunakan dalam penelitian ini karena semakin baik reputasi auditor diharapkan mampu memberikan opini yang baik mengenai laporan keuangan perusahaan, sehingga dapat memberi gambaran mengenai keadaan suatu perusahaan. Semakin tinggi reputasi auditor diharapkan semakin baik hasil audit laporan keuangan tersebut. Laporan keuangan yang diaudit oleh KAP big 4 dinilai lebih berkualitas apabila dibandingkan dengan KAP non big 4.Widowati (2013), Andry (2005), Ma'Arij dkk (2014), dan Thamida dan Lukman (2013) dalam penelitiannya menyatakan bahwa reputasi auditor memiliki pengaruh positif terhadap peringkat obligasi. Hasil yang berbeda ditemukan oleh Almilia dan Devi (2007), Febriani dkk (2012), Sejati (2010), Pandutama (2012) yang menyatakan bahwa reputasi auditor berpengaruh negatif terhadap peringkat obligasi. berdasarkan uraian latar belakang di atas dan ketidak konsistenan hasil penelitian terdahulu, maka peneliti tertarik melakukan penelitan yang berjudul "RASIO KEUANGAN, FRIM SIZE, DAN REPUTASI AUDITOR TERHADAP PERINGKAT OBLIGASI PADA PERUSAHAAN YANG TERDAFTAR DI BURSA EFEK INDONESIA PERIODE 20132016"

\section{TINJAUAN PUSTAKA}

\section{Signalling Theory}

Teori Sinyal menurut Brigham dan Houston (1999) adalah tindakan perusahaan dalam memberi sinyal kepada investor tentang bagaimana manajemen memandang perusahaan.Teori sinyal membahas bagaimana seharusnya sinyal-sinyal keberhasilan atau kegagalan manajemen (agen) disampaikan kepada pemilik (principal).Dorongan dalam memberikan sinyal timbul karena adanya informasi asimetris antara perusahaan (manajemen) dengan pihak luar, dimana investor mengetahui informasi internal perusahaan yang relatif lebih sedikit dan lebih lambat dibandingkan pihak manajemen.

Teori signal menekankan pada informasi. Dengan memberikan informasi mengenai kondisi internal suatu perusahan di harapkan asimentris informasi antara pihak manajemen dengan para investorperusahaan dapat berkurang. Dengan demikian para investorperusahaan dapat menggunakan informasi tersebut sesuai kepentingan masingmasing. Seperti investor dapat memutuskan dengan tepat untuk menambah jumlah investasinya atau bahkan menarik dana investasinya, dengan menggunakan informasi yang di berikan oleh pihak manajemen. Lembaga pemeringkat obligasi, juga dapat memberikan penilaian yang akurat terhadap obligasi yang di keluarkan perusahaan tersebut. Peringkat obligasi yang dipublikasikan diharapkan dapat menjadi signal kondisi keuangan perusahaan dan menggambarkan kemungkinan yang terjadi terkait dengan utang yang dimiliki (Ginting ,2010).

\section{OBLIGASI}

\section{Pengertian Obligasi}

Menurut Keown et al., (2011: 232) obligasi merupakan suatu jenis hutang atau surat kesanggupan bayar jangka panjang, yang 
dikeluarkan oleh peminjam, yang berjanji untuk membayar kepemegangnya dengan jumlah yang tetap setiap tahun. Menurut Bursa Efek Indonesia, obligasi merupakan surat utang jangka menengah-panjang yang dapat dipindah tangankan yang berisi janji dari pihak yang menerbitkan untuk membayar imbalan berupa bunga pada periode tertentu dan melunasi pokok utang pada waktu yang telah ditentukan kepada pihak pembeli obligasi tersebut.

\section{Karateristik Obligasi}

Menurut bursa efek Indonesia, ada 4 karakteristik obligasi, yaitu :

1. Nilai nominal (nominal value/face value/ par value)

Nilai nominal adalah nilai pokok dari suatu obligasi yang akan di terima oleh pemegang obligasi pada saat obligasi tersebut jatuh tempo.

\section{Kupon (coupon)}

Kupon (the Interest Rate) adalah nilai bunga yang diterima pemegang obligasi secara berkala.

\section{Jatuh tempo (maturity)}

Jatuh Tempo (Maturity) adalah tanggal dimana pemegang obligasi akan mendapatkan pembayaran kembali pokok atau nilai Nominal obligasi yang dimilikinya.

\section{Penerbit / Emiten (Issuer)}

Penerbit/Emiten (Issuer) merupakan perusahaan atau lembaga yang menerbitkan obligasi.

\section{Tujuan Obligasi}

Sapto Rahardjo (2003) dalam bukunya panduan berinvestasi obligasi, menjelaskan ada beberapa tujuan emiten menerbitkan obligasi, yaitu sebagai berikut :

1. Mendapatkan jumlah dana tambahan yang lebih fleksibel

Dengan menerbitkan obligasi maka perusahaan diharapkan mampu mendapatkan tambahan dana yang disesuaikan dengan kebutuhan.

2. Mendapatkan pinjaman dengan tingkat suku bunga fleksibel

Pihak perusahaan yang menerbitkan obligasi akan mendapatkan dana tambahan dengan tingkat suku bunga yang lebih fleksibel. Proses penentuan tingkat suku bunga (coupon) obligasi ditentukan berdasarkan kemampuan keuangan perusahaan serta memperhatikan kondisi tingkat suku bunga di perbankan.
3. Mendapatkan alternatif pembiayaan melalui pasar modal

Seperti diketahui, obligasi termasuk juga jenis utang jangka panjang. Perusahaan yang kesulitan melakukan pinjaman melalui perbankan bisa mencari alternatif pendanaan melalui pasar modal dengan menerbitkan obligasi sejumlah dana yang dibutuhkan

\section{Risiko Obligasi}

Dalam melakukan investasi pada obligasi, terdapat risiko-risiko yang dapat timbul, diantaranya adalah:

1. Risiko tingkat bunga pasar (market interest rate risk)

2. Risiko inflasi (inflation risk)

3. Risiko gagal bayar (default risk)

4. Risiko likuiditas (liquidity risk)

5. Risiko masa jatuh tempo (maturity risk)

6. Risiko mata uang (currency risk)

7. Risiko call (call risk)

8. Risiko Politik (political risk)

9. Risiko sektor industri (industry sector risk)

\section{Peringkat Obligasi}

Peringkat obligasi merupakan skala risiko dari beberapa obligasi yang diperdagangkan.Skala ini yang menunjukan seberapa aman bagi investor dalam membeli suatu obligasi.Keamanan suatu obligasi memberikan sinyal probabilitas kegagalan hutang suatu perusahaan.Untuk menentukan skala tersebut, diperlukan variabel-variabel yang mempengaruhi obligasi kemudian dihitung. Dari perhitungan tersebut ditemukan standar untuk mendapatkan peringkat tertentu (Lubis, 2006)

Lembaga peringkat obligasi internasional yang cukup terkenal di kalangan investor diantaranya yaitu S\&P (Standard \& Poors) Cooperation serta Moody's Investors.Sedangkan di Indonesia pemeringkat obligasi yang sering di jadikan acuan investor dalam membuat keputusan yaitu PT.PEFINDO (Pemeringkat Efek Indonesia).

Lembaga pemeringkat tersebut bertugas untuk melakukan evaluasi dan analisis atas kemungkinan macetnya pembayaran obligasi. Dengan tidak ada interpensi dari pihak mana pun, sehingga hasil analisis yang di hasilkan apa adanya sesuai informasi yang di gunakan, hasil penilaian tersebut dikeluarkan dalam bentuk peringkat yang independen. Sehingga hasil peringkat obligasi yang di keluarkan oleh lembaga pemeringkat tidak merugikan bagi investor maupun bagi emiten.

\section{Rasio Keuangan}


Rasio keuangan yang digunakan dalam penelitian ini adalah :

\section{Profitabilitas}

Nugroho (2011) Profitabilitas merupakan kemampuan perusahaan dalam menghasilkan laba.Laba sering kali menjadi salah satu ukuran kinerja perusahaan, ketika perusahaan memiliki laba yang tinggi berarti kinerjanya baik dan begitu pula sebaliknya jika perusahaan memiliki laba yang rendah maka dapat di artikan bawah kinerja perusahaan kurang baik.

\section{Likuiditas}

Menurut Brigham dan Houston (2001) mengatakan bahwa Rasio likuiditas adalah rasio yang menunjukkan hubungan kas dan aktiva lancar lainnya dengan kewajiban jangka pendek. Likuiditas perusahaan ditunjukkan oleh besar kecilnya aktiva lancar, yaitu aktiva yang mudah untuk diubah menjadi kas yang meliputi kas, surat berharga, piutang, persediaan (Sari:2011).

\section{Solvabilitas}

Lukas Setia Atmaja (2008:415) dan Sofyan Syafri Harahap (2008:306) menyatakan bahwa rasio solvabilitas mengukur hingga sejauh mana perusahaan dibiayai dari utang dengan kemampuan perusahaan yang digambarkan oleh modal (equity).

\section{Ukuran Perusahaan (frim size)}

Ukuran perusahaan secara umum dapat diartikan sebagai suatu skala yang mengklasifikasikan besar atau kecilnya suatu perusahaan dengan berbagai cara antara lain dinyatakan dalam total aset, total penjualan, nilai pasar saham, dan lain-lain.Menurut Riyanto (2008:313) "ukuran perusahan adalah besar kecilnya perusahaan dilihat dari besarnya nilai equity, nilai penjualan atau nilai aktiva"

\section{Reputasi Auditor}

"Reputasi auditor merupakan prestasi dan kepercayaan publik yang disandang auditor atas nama besar yang dimiliki auditor tersebut" (Sinarwati, 2010:7).

\section{Hipotesis Penelitian}

\section{Pengaruh Profitabilitas Terhadap Peringkat Obligasi}

Dengan nilai rasio yang tinggi mengisyaratkan bawah perusahaan memiliki kemampuan yang baik dalam menghasilkan keuntungan. Perusahaan yang memiliki nilai rasio profitabilitas yang tinggi memiliki kinerja yang baik, sehingga akan memberikan dampak yang baik terhadap peringkat obligasi. Penelitian yang di lakukan Hadianto dan Wijaya (2010).

$\mathrm{H} 1$ : profitabilitas berpengaruh positif terhadap peringkat obligasi

\section{Pengaruh Likuiditas Terhadap Peringkat Obligasi}

Dengan nilai rasio yang tinggi memberikan signal bahwa perusahaan memiliki kemampuan yang besar dalam memenuhi kewajibannya saat jatuh tempo. Begitu pun sebaliknya dengan nilai rasio yang rendah memberikan signal kalau perusahaan berpotensi tidak dapat memenuhi kewajibannya.Sehingga semakin tinggi nilai rasio likuiditas suatu obligasi, maka semakin baik peringkat suatu obligasi.Penelitian yang dilakukan satoto (2011) menyatakan bahwa likuiditas berpengaruh positif terhadap peringkat obligasi.

$\mathrm{H} 2$ : likuiditas berpengaruh positif terhadap peringkat obligasi

\section{Pengaruh Solvabilitas Terhadap Peingkat Obligasi}

Menurut Manurung (2009), jika rasio ini cukup tinggi maka hal tersebut menunjukkan tingginya penggunaan utang, sehingga hal ini dapat membuat perusahaan mengalami kesulitan keuangan dan biasanya memiliki risiko kebangkrutan yang cukup besar. Dengan demikian, semakin tinggi rasio ini berarti semakin besarpula risiko kebangkrutan yang mungkin dialami perusahaan.

H3: solvabilitas berpengaruh negatif terhadap peringkat obligasi

\section{Pengaruh Frim size Terhadap Peringkat Obligasi}

Semakin besar perusahaan, potensi mendiversifikasikan risiko non-systematic semakin besar, sehingga membuat risiko obligasi perusahaan tersebut menurun.Semakin kecil risiko obligasi perusahaan, maka semakin tinggi pula peringkat obligasi yang diperoleh perusahaan tersebut. Penelitian yang dilakukan oleh Surya (2015) dan Sejati (2010) menyatakan bahwa frim size berpengaruh positif terhadap peringkat obligasi.

H4: firm size berpengaruh positif terhadap peringkat obligasi 


\section{Pengaruh reputasi auditor Terhadap Peringkat Obligasi}

Semakin tinggi reputasi auditor diharapkan semakin baik hasil audit laporan keuangan tersebut. Laporan keuangan yang diaudit oleh KAP big 4 dinilai lebih berkualitas apabila dibandingkan dengan KAP non big 4, karena opini yang dihasilkan KAP big 4 akan lebih independen, sehingga akan dapat mengurangi agency risk sehingga kemungkinan dapat menurunkan default risk yang pada akhirnya akan meningkatkan peringkat obligasi tersebut (Sunarjanto dan Tulasi, 2013).

H5 : Reputasi auditor berpengaruh positif terhadap peringkat obligasi

\section{Kerangka konsep}

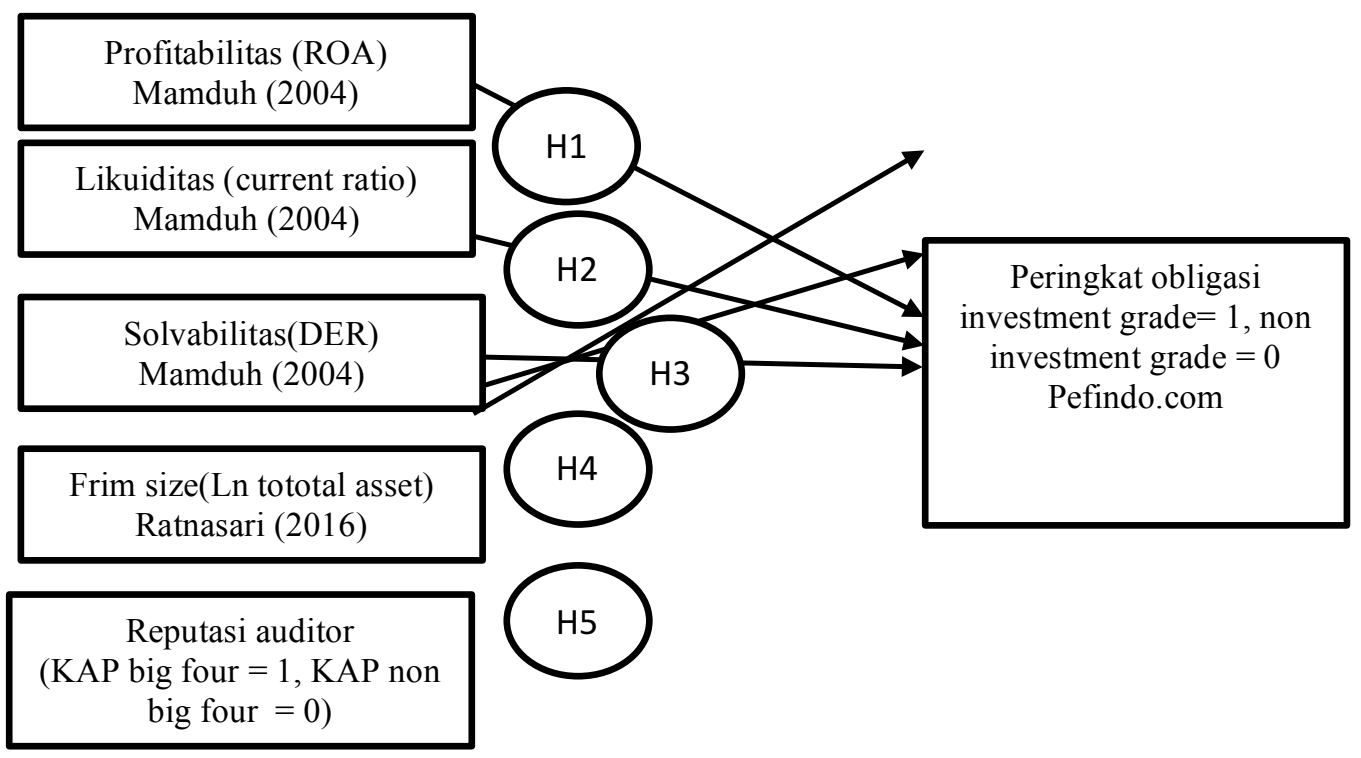

\section{METODE PENELITIAN Populasi}

Populasi dalam penelitian ini adalah seluruh perusahaan go public yang memiliki peringkat obligasi. Adapun jumlah keseluruhan perusahaan yang terdaftar di BEI pada tahun 2013-2016 yang menjadi populasi dalam penelitian ini berjumlah 131 perusahaan.

\section{Sampel}

Sampel dalam penelitian ini digunakan diambil menggunakan metode purposive sampling, yaitu metode yang menggunakan teknik penentuan sampel dengan kriteriakriteria tertentu (Sugiyono, 2005: 85).

Adapun kriteria-kriteria penentuan sampel dalam penelitian ini adalah sebagai berikut:

- Perusahaan go public yang memiliki peringkat obligasi yang diterbitkan oleh PT. PEFINDO pada periode penelitian, yaitu 2013-2016.

- Perusahaan go public yang memiliki data berupa laporan keuangan yang dibutuhkan dalam penelitian ini.
Table 3.1

Proses Penentuan Sampel Penelitian

\begin{tabular}{|l|c|}
\hline \multicolumn{1}{|c|}{ Kriteria } & $\sum$ perusahaan \\
\hline $\begin{array}{l}\text { yang memiliki peringkat } \\
\text { obligasi tidak memiliki }\end{array}$ & $\begin{array}{c}131 \\
\text { perusahaan }\end{array}$ \\
\hline $\begin{array}{l}\text { yang } \\
\text { peringkat obligasi selama } \\
\text { periode penelitian }\end{array}$ & $(90)$ \\
\hline $\begin{array}{l}\text { yang tidak memiliki data } \\
\text { berupa laporan keuangan } \\
\text { yang dibutuhkan dalam } \\
\text { penelitian ini }\end{array}$ & $(1)$ \\
\hline$\sum$ sampel & 40 \\
\hline
\end{tabular}

Sumber : data di olah, 2017

\section{Jenis dan Sumber Data \\ Jenis Data}

Jenis data yang digunakan dalam penelitian ini adalah data kuantitatif. Menurut Kasiram (2008) dalam Sujarweni (2014:39) data kuantitatif merupakan suatu proses menemukan pengetahuan yang menggunakan data berupa angka sebagai alat yang 
menganalisis keterangan mengenai apa yang ingin diketahui.

\section{Sumber Data}

Data mengenai rasio keuangan,firm size dan reputasi auditor di peroleh dari laporan keuangan perusahaan yang dan dipublikasi di situs resmi Bursa Efek Indonesia atau Indonesian Stock Exchange (IDX) www.idx.co.id dan peringkat obligasi di peroleh dari situs resmi Pemeringkat Efek Indonesi (www.pefindo.com).

\section{Metode Analisis Data Dan Pengujian Hipotesis}

\section{Model Analisis Regresi Logistik Ordinal}

Metode analisis ini digunakan untuk menguji pengaruh variabel independen yang berbentuk metrik atau non metrik terhadap variabel dependen yang bersifat kategorial (non metrik). Dalam analisis regresi logistik ordinal tidak mengharuskan asumsi multivariate normal distrubution terpenuhi dan tidak memerlukan asumsi klasik (Imam Ghazali, 2011). Adapun model analisis regresi logistik ordinal adalah sebagai berikut:

$$
\begin{aligned}
& \operatorname{Ln}\left(\frac{P 1}{1-P 1}\right)=\alpha+\beta 1(\mathrm{PROF})+\beta 2(\mathrm{SOL})- \\
& \beta 3(\mathrm{LIQUID})+\beta 4(\text { size })+\beta 5(\mathrm{RA})+\mu \\
& \operatorname{Ln}\left(\frac{P 1+P 2}{1-P 1-P 2}\right)=\alpha+\beta 1(\mathrm{PROF})+\beta 2(\mathrm{SOL})- \\
& \beta 3(\mathrm{LIQUID})+\beta 4(\text { size })+\beta 5(\mathrm{RA})+\mu \\
& \operatorname{Ln}\left(\frac{P 1+P 2+P 3}{1-P 1-P 2-P 3}\right)=\alpha+\beta 1(\mathrm{PROF})+\beta 2(\mathrm{SOL})- \\
& \beta 3(\mathrm{LIQUID})+\beta 4(\text { size })+\beta 5(\mathrm{RA})+\mu \\
& \operatorname{Ln}\left(\frac{P 1+P 2+P 3+P 4}{1-P 1-P 2-P 3-P 4}\right)=\alpha+\beta 1(\mathrm{PROF})+ \\
& \beta 2(\mathrm{SOL})-\beta 3(\mathrm{LIQUID})+\beta 4(\text { size })+\beta 5(\mathrm{RA})+\mu \\
& \operatorname{Ln}\left(\frac{P 1+P 2+P 3+P 4+P 5}{1-P 1-P 2-P 3-P 4-P 5}\right)=\alpha+\beta 1(\mathrm{PROF})+ \\
& \beta 2(\mathrm{SOL})-\beta 3(\mathrm{LIQUID})+\beta 4(\text { size })+\beta 5(\mathrm{RA})+\mu \\
& \operatorname{Ln}\left(\frac{P 1+P 2+P 3+P 4+P 5+P 6}{1-P 1-P 2-P 3-P 4-P 5-P 6}\right)=\alpha+\beta 1(\mathrm{PROF})+ \\
& \beta 2(\mathrm{SOL})-\beta 3(\mathrm{LIQUID})+\beta 4(\text { size })+\beta 5(\mathrm{RA})+\mu
\end{aligned}
$$

keterangan :

$\mathrm{P}$ : Peringkat obligasi (1 obligasi dengan peringkat AAA, 2 obligasi dengan IV. HASIL DAN PEMBAHASAN peringkat $A A, 3$ obligasi dengan peringkat A, 4 obligasi dengan BBB, 5 obligasi dengan peringkat $\mathrm{BB}, 6$ obligasi dengan peringakt $B$ )

$$
\begin{array}{ll}
\beta 1-5 & =\text { Koefisien regresi } \\
\text { PROF } & =\text { Rasio Profitabilitas } \\
\text { SOL } & =\text { Rasio Solvabilitas } \\
\text { LIQUID } & =\text { Rasio Likuiditas } \\
\text { SIZE } & =\text { Firm size } \\
\text { RA } & =\text { Reputasi auditor } \\
\mathrm{e} & =\text { error }
\end{array}
$$

\section{Defenisi Operasional Variabel Variabel Dependen}

Tabel 4.3

Definisi Operasional Peringkat Obligasi

\begin{tabular}{|l|l|}
\hline idAAA & 1 \\
\hline IdAA & 2 \\
\hline idA & 3 \\
\hline idBBB & 4 \\
\hline idBB & 5 \\
\hline idB & 6 \\
\hline \\
Sumber : data diolah, 2017
\end{tabular}

\section{Variabel Independen}

Variabel Independen Yang Digunakan Dalam Penelitian Antara Lain Sebagai Berikut :

1. Rasio Profitabilitas

Return on Asset $(\mathrm{ROA})=$ Laba Bersih : Total Aktiva.

2. Rasio Likuiditas

- Perusahaan non perbankan Current Ratio = Aktiva lancar $:$ utang lancar

- Perusahaan perbankan Loan to Deposit Ratio (LDR) $=$ kredit $:$ dana pihak ketiga

3. Rasio solvabilitas

Debt to Equity Ratio (DER) = Total Hutang : Total Ekuitas

\section{Firm size}

Firm size $($ Size $)=\mathrm{LN}$ to total asset

5. Reputasi auditor

Pengukurannya dilakukan dengan memberikan nilai 1 jika audit dilakukan oleh auditor KAP big 4 dan 0 jika audit dilakukan oleh auditor selain KAP big 4 


\begin{tabular}{|c|c|c|c|c|c|c|c|c|}
\hline \multicolumn{9}{|c|}{ Parameter Estimates } \\
\hline & & \multirow[b]{2}{*}{ Estimate } & \multirow[b]{2}{*}{$\begin{array}{l}\text { Std. } \\
\text { Error }\end{array}$} & \multirow[b]{2}{*}{ Wald } & \multirow[b]{2}{*}{ df } & \multirow[b]{2}{*}{ Sig. } & \multicolumn{2}{|c|}{$\begin{array}{l}\text { 95\% Confidence } \\
\text { Interval }\end{array}$} \\
\hline & & & & & & & $\begin{array}{l}\text { Lower } \\
\text { Bound }\end{array}$ & $\begin{array}{l}\text { Upper } \\
\text { Bound }\end{array}$ \\
\hline \multirow[t]{3}{*}{ Threshold } & $\begin{array}{l}\text { [peringkat }= \\
\text { 1] }\end{array}$ & -28.545 & 3.517 & 65.886 & 1 & .000 & -35.438 & -21.653 \\
\hline & $\begin{array}{l}\text { [peringkat = } \\
\text { 2] }\end{array}$ & -26.020 & 3.361 & 59.928 & 1 & .000 & -32.607 & -19.432 \\
\hline & $\begin{array}{l}\text { [peringkat = } \\
\text { 3] }\end{array}$ & -20.289 & 3.021 & 45.117 & 1 & .000 & -26.210 & -14.369 \\
\hline \multirow[t]{6}{*}{ Location } & Roa & .196 & .068 & 8.254 & 1 & .004 & .062 & .330 \\
\hline & Der & -.045 & .047 & .925 & 1 & .336 & -.136 & .046 \\
\hline & likuiditas & -.005 & .012 & .170 & 1 & .680 & -.029 & .019 \\
\hline & Size & 1.569 & .201 & 61.076 & 1 & .000 & -1.962 & -1.175 \\
\hline & [reputasi=0] & .426 & .402 & 1.123 & 1 & .289 & -.362 & 1.215 \\
\hline & [reputasi=1] & $0^{\mathrm{a}}$ & . & & 0 & & & \\
\hline
\end{tabular}

Link function: Logit.

a. This parameter is set to zero because it is redundant.

\section{Pembahasan}

1) Pengaruh profitabilitas terhadap peringkat obligasi

Berdasarkan tabel di atas, profitabilitas berpengaruh positif dan signifikan. Semakin tinggi profitability yang diproksikan dengan ROA dapat diartikan bahwa efisiensi laba yang diperoleh perusahaan dengan perputaran total aktiva yang dimilikinya semakin baik dan semakin tinggi kemampuan perusahaan dalam membayar bunga periodik serta melunasi pokok pinjamannya.

Menurut Hanafi dan Halim (2003) analisis profitabilitas bisa digunakan sebagai pelengkap analisis risiko, karena kemampuan perusahaan menghasilkan keuntungan mencerminkan kemampuan perusahaan memperoleh aliran kas masuk. Perusahaan yang profitabilitasnya tinggi akan memperoleh aliran kas yang baik, dengan demikian mencerminkan risiko yang lebih kecil.

Hasil penelitian ini sependapat dengan penelitian yang dilakukan oleh Burton et al (2000) dan Kamstra et al (2001) yang menunjukkan bahwa variabel profitability yang diukur dengan ROA mempunyai pengaruh yang signifikan terhadap prediksi peringkat obligasi perusahaan.

\section{2) Pengaruh solvabilitas terhadap peringkat obligasi}

Rasio solvabilitas yang di proksikan dengan Debt to Equity Ratio (DER) berpengaruh negatif terhadap peringkat obligasi. Semakin besar nilai DER suatu perusahaan mengindikasikan bahwa total utang yang dimiliki oleh perusahaan tersebut lebih besar daripada total modalnya. Kondisi tersebut menunjukkan bahwa perusahaan memiliki risiko default risk yang lebih tinggi dibandingkan perusahaan yang memiliki DER rendah. Semakin tinggi risiko default risk maka akan berpengaruh terhadap penurunan peringkat obligasi yang dimiliki perusahaan tersebut. Hasil penelitian ini sesuai dengan penelitian yang dilakukan oleh Adi Wira Pinandhita (2016).

\section{3) Pengaruh likuiditas terhadap peringkat obligasi}

Hasil uji menunjukkan koefisien regresi negatif sehingga pengaruh likuiditas terhadap peringkat obligasi bersifat negative. Rasio likuiditas suatu perusahaan terlalu tinggi juga dianggap tidak baik karena setiap nilai ekstrim mengindikasikan suatu masalah seperti penimbunan kas, banyaknya piutang yang tidak tertagih, tidak efisiennya pemanfaatan pembiayaan gratis dari pemasok dan rendahnya pinjaman jangka pendek (Fahmi, 2011).

Likuiditas yang terlalu tinggi akan berdampak buruk terhadap kinerja perusahan dlam menghasilkan laba karena aktiva lancar secara umum menghasilkan return atau tingkat keuntungan yang lebih rendah dibandingkan aktiva tetap (Hanafi, 2004). Sehingga akan berdampak terhadap penurunan peringkat obligasi perusahaan tersebut.

Penelitian ini sesuai dengan penelitian milik Sari (2016) serta Dali, Sautma dan Mariana (2015) menyatakan bahwa nilai likuiditas yang negative.

\section{4). Pengaruh size perusahaan terhadap peringkat obligasi}

Ukuran perusahaan yang di proksikan degan In total aset berpengaruh positif dan 
signifikan terhadap peringkat obligasi. Apabila jumlah aset suatu perushaan bertambah maka peringkat obligasi suatu perusahaan akan meningkat.

Menurut Magreta dan Nurmayanti (2009) semakin besar perusahaan, potensi mendiversikan risiko nonsistematik juga semakin besar sehingga membuat risiko obligasi perusahaan tersebut menurun.Menurut Devi dkk (2007) menyatakan bahwa perusahaan kecil memiliki risiko yang lebih besar dibanding dengan perusahaan besar perusahaan-perusahaan yang mempunyai aset lebih besar.

Menurut konsep penjaminan aktiva, perusahaan besar memiliki peringkat obligasi yang lebih baik daripada perusahaan kecil karena mempunyai kemampuan dalam menjaminkan aktivanya sehingga berdampak pada rendahnya risiko yang dihadapi (Tandelilin, 2010:247)

\section{5). Pengaruh reputasi auditor}

Reputasi auditor reputasi auditor berpengaruh positif terhadap peringkat obligasi. Penggunaan auditor yang berasal dari salah satu kantor akuntan publik yang termaksut big 4 KAP berdampak baik terhadap peringkat obligasi perusahaan.

Magreta dan Nurmayanti (2009) menyatakan dengan reputasi auditor yang baik maka akan memberikan hasil audit yang dapat dipercaya, Karena lebih independen, sehingga akan dapat mengurangi agency riskdan menurunkandefault risk yang pada akhirnya akan meningkatkan peringkat obligasi

Hasil pennelitian ini sesuai dengan penelitian yang dilakukan oleh Widowati (2013), Andry (2005), Ma'Arij dkk (2014), dan Thamida dan Lukman (2013).

\section{KESIMPULAN DAN SARAN}

Berdasarkan hasil penelitian yang diperoleh dan pembahasan yang telah dikemukakan pada bab sebelumnya, maka dapat diambil kesimpulan sebagai berikut:

Profitabilitas berpengaruh positif dan signifikan terhadap peringkat obligasi suatu perusahaan.Solvabilitas berpengaruh negatif terhadap peringkat obligasi.Likuiditas berpengaruh negatif terhadap peringkat obligasi perusahaan.Size berpengaruh positif dan signifikan terhadap peringkat obligasi perusahaan.Reputasi auditor berpengaruh positif terhadap peringkat obligasi.
Bagi peneliti selanjutnya dapat menambahkan variabel lain yang tidak dikaji dalam penelitian ini, seperti sinking fund, umur obligasi, jaminan dan variabel lainnya yang dapat mempengaruh peringkat obligasi perusahaan.

\section{Daftar pustaka}

Adams, Mike, Bruce Burton, dan Philip Hardwick. 2000. The Determinants of Credit Ratings in The United Kingdom Insurance Industry. Journal of Accounting andEconomics, 19

Adler Manurung, Desmon Silitonga dan Wilson Tobing. 2009. Hubungan Rasio-rasio Keuangan dengan Rating Obligasi.Paper.

Almilia, Luciana Spica dan Vieka Devi. 2007. Faktor-Faktor yang Mempengaruhi Prediksi Peringkat Obligasi pada Perusahaan Manufaktur yang Terdaftar di Bursa Efek Jakarta. Proceeding Seminar Nasional Manajemen SMART. Universitas Kristen Maranatha. Bandung. 3 November 2007

Arthur J. Keown, David F. Scott, Jr., John D. Martin, J. William Petty (2010). Manajemen Keuangan: Prinsip dan Penerapan Jilid 1 (Edisi Kesepuluh). Jakarta, PT. Indeks.

Atmaja, Lukas Setia. 2008. Teori dan Praktek Manajemen Keuangan. Yogyakarta: Penerbit ANDI

Bram, Hardiyanto. 2010. Pengaruh Kebijakan Utang, Profitabilitas, Likuiditas, Ukuran Dan Status Perusahaan Terhadap Kemungkinan Penentuan Peringkat Obligasi. Jurnal Manajemen Teori dan Terapan : Universitas Kristen Maranatha Bandung.

Brigham, Eugene F. and Joel F Houston. 1999. Manajemen Keuangan, Erlangga, Jakarta

Darmadji \& Fakhruddin, 2011, Pasar Modal di Indonesia, edisi 3, Salemba Empat, Jakarta

Hadianto, Bram dan Sienly.M.Veronika. (2010). Prediksi kebijakan utang, profitabilitas, 
likuiditas, ukuran, status perusahaan, terhadap kemungkinan penentuan peringkat obligasi: studi empirik pada perusahaan yang menerbitkan obligasi di bursa efek Indonesia.Jurnal manajemet teori dan terapan

Hanafi, Mamduh dan Abdul Halim. 2003. Analisis Laporan Keuangan. Edisi 2. Yogyakarta: UPP AMP YKPN

Hosmer, D., \& Lemeshow, S. (2000). Apllied Logistic Regressions. USA: John Wliey \& Sons.Horrigan, James O. 1966. The Determination of Long-Term Credit Standing With Financial Ratios. Journal of Accounting Research, Vol

I Made Sudana. 2011. Manajemen Keuangan Perusahaan: Teori dan Praktek. Jakarta : Penerbit Erlangga

Kamstra, Mark, dkk. 2001. "Combining Bond Rating Forecasts Using Logit" dalam The Financial Review, May, pp. 75-96

Kasiram, Moh. 2008. Metodologi Penelitian. Malang: UIN-Malang Pers.

Ma'Arij, Arinurtry, Zulbahridar, Al Azhar A. 2014. Analisis Faktor Akuntansi dan Non Akuntansi yang Mempengaruhi Prediksi Peringkat Obligasi pada Perusahaaan Non Keuangan yang Terdaftar di BEI dan diperingkat Oleh PEFINDO Periode 2009-2013. JOM FEKON. 1(2).

Magretta dan Nurmayanti Poppy. 2009. Faktorfaktor yang Mempengaruhi Prediksi Peringkat Obligasi Ditinjau dari Faktor Akuntansi dan Non Akuntansi. Jurnal bisinis dan akuntansi Vol.11, No.3 Desember 2009.

Nugroho, Elfianto. 2011. Analisis Pengaruh Likuiditas, Pertumbuhan Penjualan, Perputaran Modal Kerja, Ukuran Perusahaan dan Leverage Terhadap Profitabilitas Perusahaan (Studi pada Perusahaan Manufaktur yang Terdaftar pada BEI pada Tahun 2005 - 2009). Jurnal Ekonomi Volume 1 Nomor 7. Universitas Diponegoro.

Priambodo, R. E. A. 2006. Relevansi ORI Secara Makro dan Mikro, Usahawan, No. 11, TH. XXXV, November, h. 42-47
Sari, Fitra Kurnia. 2011. Analisis pengaruh rasio keuangan terhadap Rating Obligasi. Skripsi.UIN Maulana Malik Ibrahim.

Sejati, Grace Putri. 2010. Analisis Faktor Akuntansi dan Non Akuntansi Dalam Memprediksi Peringkat Obligasi Perusahaan Manufaktur.Bisnis dan Birokrasi, Jurnal IImu Administrasi dan Organisasi, JanApr-2010 hlm.70-78, SEJATI, Analisis Faktor Akuntansi dan Non Akuntansi.

Sujarweni, V. Wiratna. 2014. Metode Penelitian: Lengkap, Praktis, dan Mudah Dipahami. Yogyakarta: Pustaka Baru Press

Thamida, Nelly dan Hendro Lukman.2013. Analisis Faktor-Faktor yang Mempengaruhi Peringkat Obligasi pada Industri Perbankan yang Terdaftar diBursa Efek Indonesia Periode 20082012.Jurnal Akuntansi. 17(2), h:198211. 